\title{
Higher sensitivity of pad2-1 and vtc2-1 mutants to cadmium is related to lower subcellular glutathione rather than ascorbate contents
}

\author{
Barbara Eva Koffler • Lisa Polanschütz • \\ Bernd Zechmann
}

Received: 10 July 2013 / Accepted: 25 October 2013 / Published online: 27 November 2013

(C) The Author(s) 2013. This article is published with open access at Springerlink.com

\begin{abstract}
Cadmium (Cd) interferes with ascorbate and glutathione metabolism as it induces the production of reactive oxygen species (ROS), binds to glutathione due to its high affinity to thiol groups, and induces the production of phytochelatins (PCs) which use glutathione as a precursor. In this study, changes in the compartment specific distribution of ascorbate and glutathione were monitored over a time period of 14 days in Cd-treated $(50$ and $100 \mu \mathrm{M})$ Arabidopsis Col-0 plants, and two mutant lines deficient in glutathione (pad2-1) and ascorbate (vtc2-1). Both mutants showed higher sensitivity to $\mathrm{Cd}$ than Col-0 plants. Strongly reduced compartment specific glutathione, rather than decreased ascorbate contents, could be correlated with the development of symptoms in these mutants suggesting that higher sensitivity to $\mathrm{Cd}$ is related to low glutathione contents rather than low ascorbate contents. On the subcellular level it became obvious that long-term treatment of wildtype plants with $\mathrm{Cd}$ induced the depletion of glutathione and ascorbate contents in all cell compartments except chloroplasts indicating an important protective role for antioxidants in chloroplasts against $\mathrm{Cd}$. Additionally, we could observe an immediate decrease of glutathione and ascorbate in all cell compartments $12 \mathrm{~h}$ after $\mathrm{Cd}$ treatment indicating that glutathione and ascorbate are either withdrawn from or not redistributed into other organelles after their production in chloroplasts, cytosol (production centers for glutathione) and mitochondria
\end{abstract}

Handling Editor: Néstor Carrillo

Electronic supplementary material The online version of this article (doi:10.1007/s00709-013-0576-x) contains supplementary material, which is available to authorized users.

B. E. Koffler $\cdot$ L. Polanschütz $\cdot$ B. Zechmann $(\bowtie)$

Institute of Plant Sciences, University of Graz, Schubertstrasse 51, 8010 Graz, Austria

e-mail: bernd.zechmann@uni-graz.at (production center for ascorbate). The obtained data is discussed in respect to recently proposed stress models involving antioxidants in the protection of plants against environmental stress conditions.

Keywords Arabidopsis - Ascorbate · Cadmium · Glutathione $\cdot$ Transmission electron microscopy

\section{Introduction}

Contaminations of soils with heavy metals such as cadmium (Cd) are a severe problem for plant growth and development as they accumulate and negatively interfere with many physiological processes in plants. Environmental pollution by metals such as Cd became extensive in the late 19th and early 20th century as mining and industrial activities increased (Benavides et al. 2005; Gallego et al. 2012). Anthropogenic sources like zinc smelting, burning of fuel, waste incinerators, urban traffic, cement factories, and $\mathrm{Cd}$ as a by-product of phosphate fertilizers have led to $\mathrm{Cd}$ pollution in the environment (Sanità di Toppi and Gabbrielli 1999; DalCorso et al. 2008; Jozefczak et al. 2012). Although Cd is not an essential element, it is readily absorbed by the roots and transported through xylem and phloem to different parts of the plants (Mendoza-cózatl et al. 2008; DalCorso et al. 2008). Visible symptoms of Cd toxicity in plants are leaf roll, chlorosis, browning of root tips and reduced growth (Baryla et al. 2001; Schützendübel and Polle 2002; Chen et al. 2003; Gratão et al. 2005; Maughan et al. 2010). Inside the plant $\mathrm{Cd}$ leads to an alteration of the chloroplast ultrastructure, disturbs the synthesis of chlorophyll and carotenoids, inhibits the enzyme activity of the Calvin cycle and leads to $\mathrm{CO}_{2}$ deficiency due to stomatal closure, which cause the inhibition of photosynthesis (Ding et al. 2006; Ekmekci et al. 2008; He et al. 2008; Gratão et al. 2009; 
Bouzon et al. 2012). Additionally, Cd causes lipid peroxidation, disrupts cell transport processes, reduces the uptake of essential mineral nutrients, reduces the activity of various enzymes and is responsible for chromosomal aberrations (Clemens et al. 2001; Schützendübel and Polle 2002; Ding et al. 2006; Sanità di Toppi et al. 2008; Gratão et al. 2012). Indirectly, high concentrations of $\mathrm{Cd}$ lead to oxidative stress which activates the accumulation of anti-oxidative defense enzymes and antioxidants like ascorbate and glutathione (Sanità di Toppi and Gabbrielli 1999; Hegedüs et al. 2001; Gratão et al. 2005; Paradiso et al. 2008; Ekmekci et al. 2008; Xu et al. 2008; DalCorso et al. 2008; Gill and Tuteja 2010; Yadav 2010; Monteiro et al. 2011; Gallego et al. 2012; Shan et al. 2012; Zelinova et al. 2013) which detoxify reactive oxygen species (ROS) either through reactions catalyzed by peroxidases or through the ascorbate glutathione cycle (Foyer and Noctor 2005; Iannone et al. 2010; Foyer and Noctor 2011; Noctor et al. 2012). In addition, Cd has a high affinity to thiol groups and forms complexes with reduced glutathione which are then transported into vacuoles. Glutathione is also able to protect proteins by reversible binding to their $\mathrm{SH}$ groups which protects them from oxidation by ROS and inhibits the binding of Cd (Rauser 2001; Maksymiec and Krupa 2006; Semane et al. 2007; DalCorso et al. 2010; Jozefczak et al. 2012). On top glutathione serves as a direct precursor of phytochelatins (PCs), which together with metallothioneins detoxify $\mathrm{Cd}$ by complexation, transportation, and deposition in the vacuole (Akhter et al. 2012).

Considering the importance of ascorbate and glutathione in the protection against $\mathrm{Cd}$ changes in the contents of these antioxidants are well documented in Cd-treated plants. After treatment with $10 \mu \mathrm{M} \mathrm{Cd}$ sulfate for $24 \mathrm{~h}$, Arabidopsis thaliana plants showed reduced ascorbate contents in roots (Smeets et al. 2009) and leaves (Keunen et al. 2013). While experiments with Brassica juncea showed increased levels of ascorbate in roots after Cd treatment (Mohamed et al. 2012), decreased ascorbate levels were found after long-term $\mathrm{Cd}$ exposure of Ceratophyllum demersum (Aravind and Prasad 2005), Brassica campestiris (Anjum et al. 2008) and Bechmeria nivea (L.) Gaud (Liu et al. 2007). Glutathione levels in Cd-treated plants were found to be decreased, e.g., in soybean leaves (Noriega et al. 2012), in cotyledons and embryonic axes of pea seed (Smiri et al. 2011), in Cd sensitive rice seedlings (Chao et al. 2011), in B. campestiris leaves (Anjum et al. 2008), and within glandular trichomes of Cucurbita pepo (Kolb et al. 2010). Other studies revealed either unchanged glutathione contents for example within Cd tolerant rice seedlings (Chao et al. 2011), or increased glutathione levels like in $B$. juncea shoots and roots (Mohamed et al. 2012), in leaves of Bechmeria nivea (Liu et al. 2007) and in Arabidopsis plants (Wójcik and Tukiendorf 2011). Even though these investigations paint a clear picture about the importance and functions of ascorbate and glutathione in the protection against $\mathrm{Cd}$ the results of these studies differ in time points, $\mathrm{Cd}$ concentration, plant species as well as plant organs and tissues. In particular, the situation during $\mathrm{Cd}$ exposure over a period of 14 days in Arabidopsis remains unclear. As stress responses in plants strongly depend on plant species, the state of acclimation and adaptation, severity and duration of stress (Tausz et al. 2004; Gratão et al. 2008; Kranner et al. 2010), it is important to monitor different severities of stresses at different time points in one plant species in order to get a deeper insight into the stress response of a plant. Additionally, Cd-induced stress responses in plants have mainly been investigated by using biochemical methods in order to investigate ascorbate and glutathione contents in whole leaves or organs (Liu et al. 2007; Anjum et al. 2008; Chao et al. 2011; Smiri et al. 2011; Wójcik and Tukiendorf 2011; Noriega et al. 2012; Mohamed et al. 2012). Thus, results about the situation concerning glutathione or ascorbate contents are rarely available for individual cell compartments (Kolb et al. 2010). Since Cd enters the cytosol first and affects this cell compartment stronger than others compartment specific data of ascorbate and glutathione contents could give valuable information about the subcellular importance of ascorbate and glutathione in the protection against $\mathrm{Cd}$.

Thus, the aim of this study was to investigate the compartment-specific distribution of ascorbate and glutathione in Arabidopsis plants during Cd exposure. Different concentrations and time points of $\mathrm{Cd}$ treatment were investigated over a period of 14 days in order to clarify the dynamic compartment specific protection of these key antioxidants against $\mathrm{Cd}$ exposure. Additionally, we compared the situation in the ascorbate and glutathione deficient mutant vtc2-1 (60\% less ascorbate than Col-0; Zechmann et al. 2011c) and pad2-1 (80\% less glutathione than Col-0; (Parisy et al. 2006; Zechmann et al. 2008), respectively, in order to clarify how low ascorbate and glutathione contents contribute towards $\mathrm{Cd}$ sensitivity.

\section{Materials and methods}

Plant material and growth conditions

After stratification for 4 days at $4{ }^{\circ} \mathrm{C}$, seeds of $A$. thaliana accession Col-0 and two Arabidopsis mutants (pad2-1, vtc21 ) were grown in a mixture of vermiculite and sand (2:1) in growth chambers with a $10 / 14 \mathrm{~h}$ day/night photoperiod. Temperatures were $22{ }^{\circ} \mathrm{C}$ during daytime and $18{ }^{\circ} \mathrm{C}$ at night. The relative humidity was $60 \%$ and the relative soil water content was kept at $100 \%$. The light intensity was $150 \mu \mathrm{M} \mathrm{m}^{-2} \mathrm{~s}^{-1}$.

For Cd treatment, 6- to 8-week-old plants were removed from the pots and were gently washed with water to eliminate 
vermiculite and sand from the roots. The plants were transferred into plastic dishes $(1,500 \mathrm{ml})$ covered with a nylon mesh that held up the stems and leaves whereas the roots immersed into the solution. Oxygen was supplied to the solution through an aquarium pump. For treatment the dishes were filled either with nutrient solution as control or nutrient solution mixed with $\mathrm{Cd}$ sulfate $(50$ and $100 \mu \mathrm{M})$. Cd treatment was performed for different time points $(12 \mathrm{~h}, 24 \mathrm{~h}$, $48 \mathrm{~h}, 96 \mathrm{~h}, 7$ days and 14 days) with plants of different age so that by the time of harvesting, all plants were 8 weeks old. The solution contained $5 \mathrm{mM} \mathrm{KNO}, 1 \mathrm{mM} \mathrm{KH}_{2} \mathrm{PO}_{4}$, $2 \mathrm{mM} \mathrm{Mg}\left(\mathrm{NO}_{3}\right)_{2} \cdot 6 \mathrm{H}_{2} \mathrm{O}, 2.5 \mathrm{mM} \mathrm{CaSO}{ }_{4} \cdot 2 \mathrm{H}_{2} \mathrm{O}, 1 \mathrm{mM}$ $\mathrm{MgSO}_{4} \cdot 7 \mathrm{H}_{2} \mathrm{O}, 70 \mu \mathrm{M}$ EDTA-FeNa, $4 \mathrm{mM} \mathrm{Ca}\left(\mathrm{NO}_{3}\right)_{2} \cdot 4 \mathrm{H}_{2} \mathrm{O}$, $0.9 \mu \mathrm{M} \mathrm{ZnCl} 2,30 \mu \mathrm{M} \mathrm{H}_{3} \mathrm{BO}_{3}, 0.9 \mu \mathrm{M} \mathrm{CuCl}_{2} \cdot 2 \mathrm{H}_{2} \mathrm{O}, 0.5 \mu \mathrm{M}$ $\mathrm{MoO}_{3}, 20 \mu \mathrm{M} \mathrm{MnCl}{ }_{2} \cdot 4 \mathrm{H}_{2} \mathrm{O}$ and was as well as the $\mathrm{Cd}$ solution changed every 4 days. The $\mathrm{pH}$ value of the solution was adjusted to 6.5 .

Sample preparation for transmission electron microscopy

Two hours after the onset of the light period the center of three different leaves (always taken from the fourth rosette) from each sample were cut into $1.5-\mathrm{mm}^{2}$ pieces on a modeling wax plate in a drop of $2.5 \%$ paraformaldehyde $/ 0.5 \%$ glutardialdehyde in $0.06 \mathrm{M}$ Sørensen phosphate buffer (pH 7.2). The samples were then transferred into glass vials filled with the same fixative for $90 \mathrm{~min}$ at room temperature (RT) and were then dehydrated with increasing concentrations of acetone $(50 \%, 70 \%, 90 \%)$. Subsequently, specimens were infiltrated with increasing concentrations of LR-White resin (30\%, $60 \%, 100 \%$; London Resin Company Ltd., Berkshire, UK) mixed with acetone ( $90 \%$ ) for at least $3 \mathrm{~h}$ at each step at RT. Finally, the samples where embedded in pure, fresh LRWhite resin and polymerized at $50{ }^{\circ} \mathrm{C}$ for $48 \mathrm{~h}$ in small plastic cups under anaerobic conditions. Ultrathin sections of about $80 \mathrm{~nm}$ were generated by cutting the samples with a Reichert Ultracut S ultramicrotome (Leica Microsystems, Wetzlar, Germany).

Immunogold labeling of ascorbate and glutathione

Cytohistochemical investigation were performed as described previously (Zechmann et al. 2011a, b, c). Ultrathin sections were blocked with $2 \%$ bovine serum albumin (BSA; SigmaAldrich, St. Louis, MO, USA) in phosphate buffered saline (pH 7.2). Subsequently the samples were treated with the primary antibodies against ascorbate (anti-ascorbate rat polyclonal IgG; Abcam plc, Cambridge, UK) diluted 1:300 in phosphate buffered saline containing $1 \%$ BSA and glutathione (anti-glutathione rabbit polyclonal IgG, Millipore Corp., Billerica, Ma, USA) diluted 1:50 in phosphate buffered saline with $1 \%$ goat serum for $2 \mathrm{~h}$ at RT. Then the specimens where rinsed three times with phosphate buffered saline containing $1 \%$ BSA and treated with a $10-\mathrm{nm}$ goldconjugated secondary antibody (goat anti-rat IgG for ascorbate labeling and goat anti-rabbit IgG [British BioCell International, Cardiff, UK] for glutathione labeling) diluted 1:100 for ascorbate and 1:50 for glutathione in phosphatebuffered saline containing $1 \%$ BSA for $90 \mathrm{~min}$ at RT. Next, the samples were washed two times in distilled water and post-stained with uranyl acetate ( $2 \%$ dissolved in aqua bidest) for $20 \mathrm{~s}$. The samples were analyzed with a Philips CM10 transmission electron microscope where micrographs of randomly photographed immunogold-labeled sections at 8,900fold magnification were taken. Micrographs of randomly photographed immunogold labeled sections were digitized and gold particles were counted automatically using the software package Cell D with the particle analysis tool (Olympus, Life and Material Science Europa GmbH, Hamburg, Germany) in different visually identified and manually traced cell structures (mitochondria, plastids, nuclei, peroxisomes, the cytosol, vacuoles). Unspecific background labeling was determined on the sections (outside the specimen) and subtracted from the values obtained in the sample. A minimum of 20 (peroxisomes and vacuoles) to 60 (other cell structures) sectioned cell structures of at least 15 different cells were analyzed for gold particle density per sample. For statistical evaluation at least two different samples for each treatment ( $n=20$ for peroxisomes and vacuoles, $n=60$ for other cell compartments) were analyzed to gain the number of gold particles per $\mu \mathrm{m}^{2}$ per compartment. Differences in gold particle density of Cd-treated and control samples were calculated in percent. Control plants showed similar (not significantly different) subcellular ascorbate and glutathione contents throughout the experiment. Thus, a mean of the determined subcellular ascorbate and glutathione contents was calculated, defined as control and used for calculating significant differences between Cd-treated and control samples. The obtained data were statistically evaluated using Statistica (Stat-Soft Europe, Hamburg, Germany). For statistical analyses, the Mann-Whitney $U$ was applied.

Several negative controls were made to support the specificity of the immunogold procedure. Negative controls were treated either with (1) gold conjugated secondary antibody (goat anti-rat $\operatorname{IgG}$ for ascorbate and goat anti-rabbit $\operatorname{IgG}$ for glutathione) without prior incubation of the section with the primary antibodies, (2) non-specific secondary antibody (goat anti rabbit IgG for ascorbate and goat anti rat IgG for glutathione), (3) preimmune serum instead of the primary antibody and (4) primary antibody against ascorbate and glutathione pre-adsorbed with an excess of reduced and oxidized ascorbate and glutathione, respectively, for $2 \mathrm{~h}$ prior to labeling of the sections. For the latter, a solution containing either $10 \mathrm{mM}$ of ascorbic acid, dehydroascorbic acid, reduced or oxidized glutathione was incubated with or without $0.5 \%$ glutardialdehyde for $1 \mathrm{~h}$. When glutardialdehyde was used 
then its excess was saturated by incubation for $30 \mathrm{~min}$ in a solution of $1 \%(\mathrm{w} / \mathrm{v}) \mathrm{BSA}$. The resulting solutions were both used in independent experiments to saturate the anti-ascorbate and glutathione antibodies for $2 \mathrm{~h}$ prior to its use in the immunogold labeling procedure described above. Labeling on sections treated as negative controls showed no or only very little gold particles bound to ascorbate and glutathione which was similar to previous results obtained by using the same methods in different plant species (Zechmann and Müller 2010; Zechmann et al. 2011c). We have shown in previous reports that the antibody against glutathione binds to free reduced and oxidized glutathione and that it does not bind to glutathione conjugated with monochlorobimane through the SH group and glutationylated proteins (Zechmann et al. 2008; Queval et al. 2011). Additionally, it does not bind to PCs as it binds to the amino group and both carbonyl groups of glutathione - the latter are not available for the antibody in PCs (personal communication with Signature Immunologics Inc.). The glutathione and ascorbate status in the glutathione and ascorbate deficient mutants used in this study (pad2-1 and vtc2-1, respectively) has been studied extensively in previous studies and showed a good correlation between data obtained on the subcellular level and data obtained on the whole leaf level with biochemical methods (Parisy et al. 2006; Zechmann et al. 2008; Zechmann and Müller 2008; Zechmann et al. 2011c). The immunogold localization of ascorbate in mutants deficient in ascorbate (vtc2-1 and $v t c 2-2)$ revealed a strong decrease of subcellular ascorbate specific labeling between $50 \%$ and $60 \%$ when compared to A. thaliana Col-0 plants. This data correlated well with biochemical measurements which revealed a similar decrease of ascorbate contents in whole leaves of these mutants (Zechmann et al. 2011c). The specificity and accuracy of the immunogold labeling method for glutathione was demonstrated on glutathione deficient mutants pad2-1 and $r m l 1$, which both showed a strong decrease of compartment-specific glutathione labeling of up to $91 \%$ and $98 \%$, respectively. This data correlated well with biochemical measurements of glutathione in these mutants revealing a similar decrease in whole leaves of these mutants (Vernoux et al. 2000; Cairns et al. 2006; Parisy et al. 2006).

\section{Results}

\section{Visual symptoms}

Leaves of plants that were treated without $\mathrm{Cd}$ did not develop chlorosis and necrosis (Figs. 1a,e,i and 2a,e,i). First negative effects of $\mathrm{Cd}$ treatment in the form of local chlorotic spots could be found on wildtype plants 14 days after the treatment with $50 \mu \mathrm{M} \mathrm{Cd}$ (Fig. 1d). Leaves of pad2-1 mutants showed first signs of chlorosis and necrosis after 7 days of $50 \mu \mathrm{M} \mathrm{Cd}$ treatment which became more severe 14 days after treatment with $50 \mu \mathrm{M} \mathrm{Cd}$ (Fig. 1g, h.). vtc2-1 mutants showed minor signs of chlorosis after 7 days and strong chlorotic spots 14 days after the treatment with $50 \mu \mathrm{M} \mathrm{Cd}$ (Fig. 1k, 1). After treatment with $100 \mu \mathrm{M} \mathrm{Cd}$ wildtype plants developed chlorosis after 7 days, which became more severe 14 days after $\mathrm{Cd}$ treatment (Fig. 2c,d). Leaves of pad2-1 mutants showed first signs of chlorosis after $96 \mathrm{~h}$ (Fig. 2f) and both chlorosis and necrosis after 7 days of $100 \mu \mathrm{M} \mathrm{Cd}$ treatment (Fig. 2g). Large necrotic areas and chlorotic spots were visible on leaves of pad2-1 mutants 14 days after $\mathrm{Cd}$ treatment (Fig. 2h). Leaves of vtc2-1 mutants showed first signs of chlorosis after $96 \mathrm{~h}$ (Fig. 2j) of treatment with $100 \mu \mathrm{M} \mathrm{Cd}$ (Fig. 2j). Chlorosis and necrosis became more severe 7 and 14 days after $100 \mu \mathrm{M}$ of $\mathrm{Cd}$ treatment but did not reach the extent observed in pad2-1 and Col-0 (Fig. 2k,1).

Immunogold labeling of ascorbate

\section{$50 \mu M C d$}

The subcellular distribution of ascorbate in control plants was similar in most cell compartments to what has been reported previously (Zechmann et al. 2011c). Wildtype plants and pad2-1 mutants contained similar levels of ascorbate in all cell compartments whereas the vtc2-1 mutant contained between $-50 \%$ and $-75 \%$ less ascorbate (vacuoles and nuclei, respectively) than the wildtype (Table 1). These results are similar to what has been described in previous studies which revealed that the vtc2-1 mutant contained between -50 and $-60 \%$ less ascorbate than wildtype plants (Zechmann et al. 2011c).

Mitochondria of wildtype plants showed significant decreased levels of gold particles bound to ascorbate after $12 \mathrm{~h}$ $(-49 \%), 24 \mathrm{~h}(-52 \%)$ and $48 \mathrm{~h}(47 \%)$ and significant increased levels after 7 days $(80 \%)$ after treatment with $50 \mu \mathrm{M} \mathrm{Cd}$ (Fig. 3). In chloroplasts decreased amounts of gold particles bound to ascorbate could be observed after $48 \mathrm{~h}$ $(-18 \%)$, whereas increased ascorbate levels could be observed after $96 \mathrm{~h}(187 \%)$ of $\mathrm{Cd}$ treatment when compared to the control. The amount of gold particles in nuclei significantly decreased after exposure to $50 \mu \mathrm{M} \mathrm{Cd}$ for $12 \mathrm{~h}$ $(-31 \%)$ and 14 days $(-36 \%)$ and showed increased levels after $96 \mathrm{~h}(82 \%)$ compared to the control. In the cytosol decreased ascorbate levels could be found after $24 \mathrm{~h}$ $(-43 \%)$ and $48 \mathrm{~h}(-48 \%)$ after treatment with $50 \mu \mathrm{M} \mathrm{Cd}$. In peroxisomes significantly decreased ascorbate levels could be observed after $12 \mathrm{~h}(-51 \%)$ and increased levels after $96 \mathrm{~h}$ $(147 \%)$. In the vacuole, the numbers of gold particles bound to ascorbate showed a decrease after 7 days $(-46 \%)$ whereas no change was found at the other time points when compared to the control (Fig. 3, Fig. S1). 
Fig. 1 Representative images of leaves from Arabidopsis thaliana Col-0 (a-d), and the mutants pad2-1 (e-h) and vtc2-1 (i-l) treated with $50 \mu \mathrm{M}$ of Cd for $0(\mathbf{a}$, $\mathbf{e}, \mathbf{i}), 96 \mathrm{~h}(\mathbf{b}, \mathbf{f}, \mathbf{j}), 7$ days $(\mathbf{c}, \mathbf{g}$, k) and 14 days $(\mathbf{d}, \mathbf{h}, \mathbf{l})$. First signs of Cd-induced alterations such as chlorotic lesions could be observed in the mutants 7 days ( $\mathbf{g}$, k) after Cd treatment which became more prominent and covered larger areas 14 days $(\mathbf{h}, \mathbf{l})$ after Cd treatment. Wildtype plants showed first signs of chlorotic lesions starting at 14 days after $\mathrm{Cd}$ treatment (d)
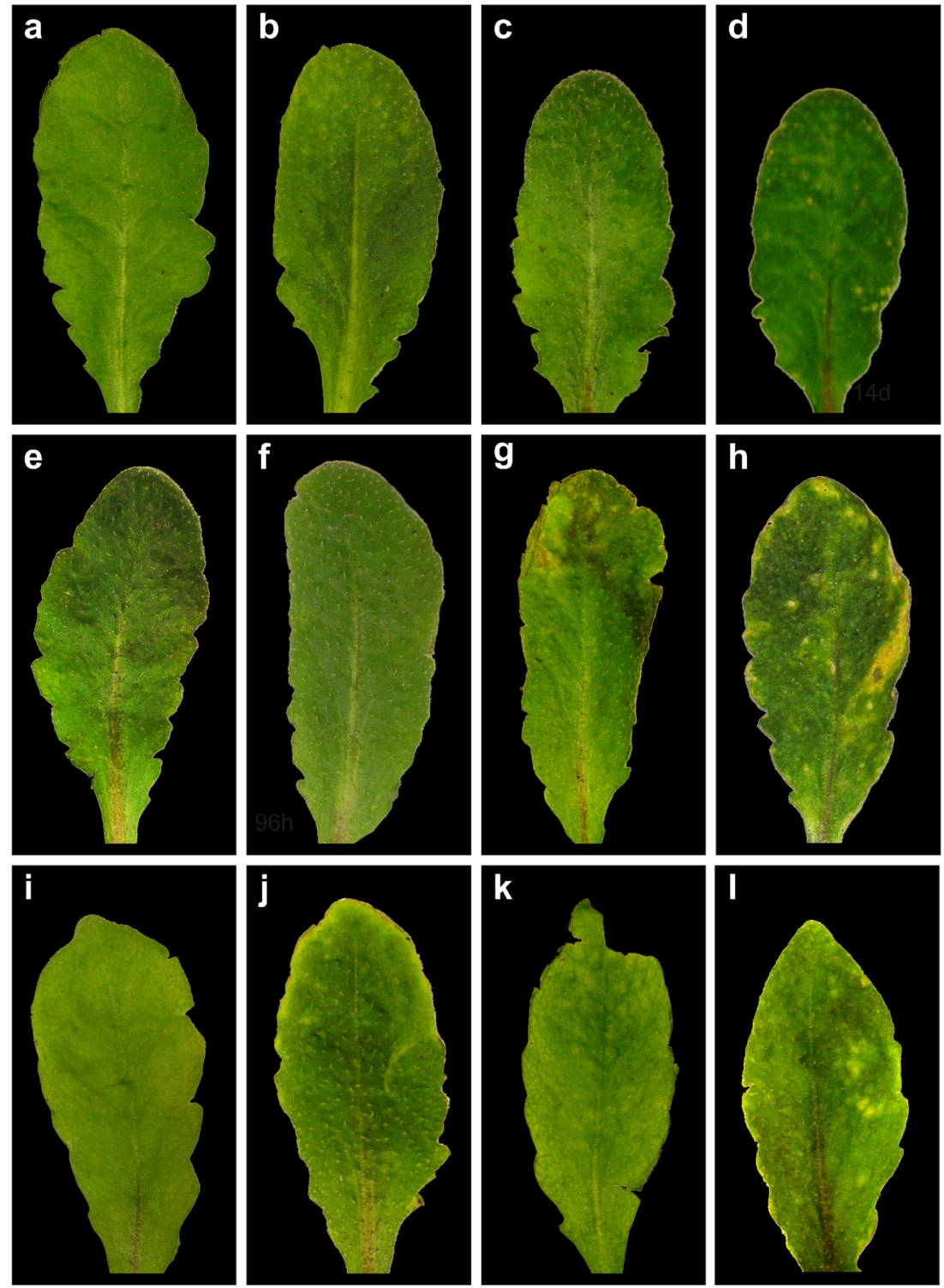

Mitochondria of pad2-1 mutants showed significantly decreased ascorbate levels after $12 \mathrm{~h}(-38 \%)$ and 14 days $(-49 \%)$ and increased levels after $48 \mathrm{~h}(44 \%)$ after treatment with $50 \mu \mathrm{M} \mathrm{Cd}$ (Fig. 3). The amount of gold particles bound to ascorbate in chloroplasts significantly decreased after $12 \mathrm{~h}$ (-62\%), whereas after $48 \mathrm{~h}(58 \%)$ and 7 days $(60 \%)$ an increase of gold particles compared to the control could be observed. In nuclei, increased amounts of gold particles bound to ascorbate could be observed after $48 \mathrm{~h}(51 \%)$ after $\mathrm{Cd}$ treatment. In the cytosol, the ascorbate levels decreased significantly (between $-43 \%$ and $-52 \%$ ) after 12, 24 and $96 \mathrm{~h}$, whereas after $48 \mathrm{~h}$ significantly increased ascorbate levels $(26 \%)$ could be observed. The amount of gold particles bound to ascorbate in peroxisomes significantly increased after exposure to $\mathrm{Cd}$ for $12 \mathrm{~h} \mathrm{(12 \% ),} 48 \mathrm{~h} \mathrm{(127 \% )} \mathrm{and} 96 \mathrm{~h}(10 \%)$ and decreased after $24 \mathrm{~h}(43 \%)$ and 14 days $(68 \%)$. The vacuole showed significant increased ascorbate levels after $\mathrm{Cd}$ treatment for $24 \mathrm{~h}(42 \%), 48 \mathrm{~h}(66 \%), 96 \mathrm{~h}(32 \%)$ and 7 days (30\%) compared to the control (Fig. 3, Fig. S2).

In the mitochondria of $v t c 2-1$ mutants, the labeling density was significantly increased after $48 \mathrm{~h}(112 \%)$, whereas decreased levels of ascorbate were found after $12 \mathrm{~h}(-36 \%)$ and 14 days ( $-70 \%$ ) after treatment with $50 \mu \mathrm{M} \mathrm{Cd}$ (Fig. 3). In chloroplasts, the number of gold particles bound to ascorbate was significantly decreased after $12 \mathrm{~h}(-39 \%)$ and 7 days (44\%) whereas after $48 \mathrm{~h}$ an increase of $100 \%$ could be observed. The amount of gold particles bound to ascorbate in nuclei was significantly increased after $48 \mathrm{~h}(89 \%)$ and $96 \mathrm{~h}$ (62\%) whereas decreased levels could be observed after 14 days $(-70 \%)$ after treatment with $50 \mu \mathrm{M} \mathrm{Cd}$. In the cytosol ascorbate levels significantly decreased after $12 \mathrm{~h}(-36 \%)$ and 14 days ( $-47 \%$ ) and increased after $48 \mathrm{~h}$ ( $89 \%$ ) compared to 
Fig. 2 Representative images of leaves from Arabidopsis thaliana Col-0 (a-d), and the mutants pad2-1 (e-h) and vtc2-1 (i-l). Leaves derived from plants which were treated without $\mathrm{Cd}$ for 14 days $(\mathbf{a}, \mathbf{e}, \mathbf{i})$ or with $100 \mu \mathrm{M}$ of Cd for $96 \mathrm{~h}(\mathbf{b}, \mathbf{f}, \mathbf{j}), 7$ days $(\mathbf{c}$, $\mathbf{g , ~ k )}$ and 14 days $(\mathbf{d}, \mathbf{h}, \mathbf{l})$. First signs of Cd-induced alterations such as the appearance of chlorosis and necrosis could be observed in the mutants $96 \mathrm{~h}(\mathbf{f}, \mathbf{j})$ after $\mathrm{Cd}$ treatment which became more prominent and covered larger areas 7 days $(\mathbf{g}, \mathbf{k})$ and 14 days (h, $\mathbf{l})$ after $\mathrm{Cd}$ treatment. Wildtype plants showed first signs of chlorotic lesions starting at 7 days after $\mathrm{Cd}$ treatment (c) which covered larger areas 14 days after $\mathrm{Cd}$ treatment (d)
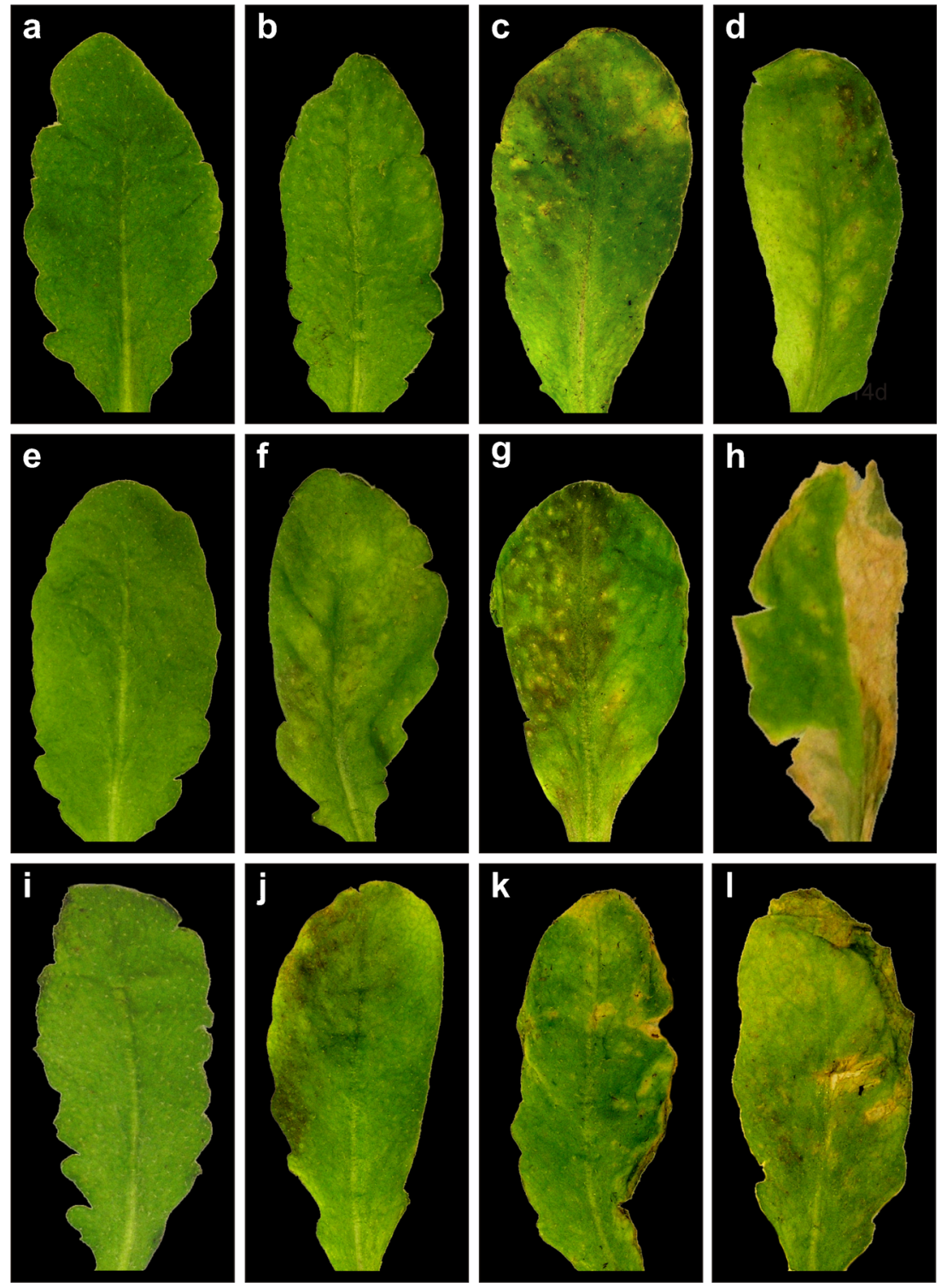

Table 1 Values are means with standard errors and document the total amount of gold particles bound to ascorbate per $\mu \mathrm{m}^{2}$ in different cell compartments of Arabidopsis thaliana [L.] Heynh. ecotype Columbia (Col-0), pad2-1 and vtc2-1 mutants grown under control conditions

\begin{tabular}{llll}
\hline & Col-0 & pad2-1 & $v t c 2-1$ \\
\hline Mitochondria & $7 \pm 0.5^{\mathrm{cd}}$ & $10 \pm 1^{\mathrm{b}}$ & $2 \pm 0.7^{\mathrm{hg}}$ \\
Chloroplasts & $6 \pm 0.4^{\mathrm{d}}$ & $6 \pm 0.5^{\mathrm{d}}$ & $3 \pm 0.3^{\mathrm{ef}}$ \\
Nuclei & $16 \pm 0.8^{\mathrm{a}}$ & $12 \pm 0.8^{\mathrm{b}}$ & $4 \pm 0.6^{\mathrm{e}}$ \\
Peroxisomes & $10 \pm 0.9^{\mathrm{b}}$ & $12 \pm 1^{\mathrm{b}}$ & $4 \pm 0.9^{\mathrm{e}}$ \\
Cytosol & $10 \pm 0.7^{\mathrm{b}}$ & $9 \pm 0.8^{\mathrm{bc}}$ & $3 \pm 0.6^{\mathrm{ef}}$ \\
Vacuoles & $2 \pm 0.2^{\mathrm{hg}}$ & $2 \pm 0.1^{\mathrm{hg}}$ & $1 \pm 0.2^{\mathrm{g}}$ \\
\hline
\end{tabular}

$n>20$ for peroxisomes and vacuoles and $n>60$ for other cell structures. Different lowercase letters indicate significant differences $(P<0.05)$ analyzed with the Kruskal-Wallis test followed by post-hoc comparison according to Conover the control. Generally the ascorbate levels in peroxisomes were similar to control levels except after $48 \mathrm{~h}$ after $\mathrm{Cd}$ treatment where an increase of $82 \%$ could be observed. The vacuole showed increased ascorbate levels after $48 \mathrm{~h}(39 \%)$ and $96 \mathrm{~h}(33 \%)$ compared to the control (Fig. 3, Fig. S3).

\section{$100 \mu M C d$}

In the mitochondria of wildtype plants, the labeling density of ascorbate was significantly decreased after $24 \mathrm{~h}(-42 \%)$ and $48 \mathrm{~h}(-51 \%)$ after treatment with $100 \mu \mathrm{M} \mathrm{Cd}$ (Fig. 4). In plastids decreased amounts of gold particles bound to ascorbate could be observed after $12 \mathrm{~h}(-31 \%), 24 \mathrm{~h}(-37 \%)$ and 7 days $(-24 \%)$, whereas significant increased levels was found after $96 \mathrm{~h}(48 \%)$ and 14 days (30\%) when compared to the control. In nuclei, the gold particle density bound to ascorbate decreased 
Fig. 3 Compartment specific changes in ascorbate labeling density at different time points after the treatment of $50 \mu \mathrm{M} \mathrm{Cd}$. Graphs show the percentage of increase and decrease of gold particles bound to ascorbate per $\mu \mathrm{m}^{2}$ in mesophyll cells of Arabidopsis thaliana Col-0 plants (black squares) and the Arabidopsis mutants pad2-1 (red circles) and vtc2-2 (blue triangles). Differences were calculated by comparing Cdtreated samples with control samples which were treated with nutrient solution without $\mathrm{Cd}$ (values can be found in Table 1). $n>20$ for peroxisomes and vacuoles and $n>60$ for other cell structures. Data are means with standard errors. Significant differences were calculated using the Mann-Whitney $U$-test; *, ** and $* * *$ indicate significance at the $0.05,0.01$ and 0.001 levels of confidence, respectively
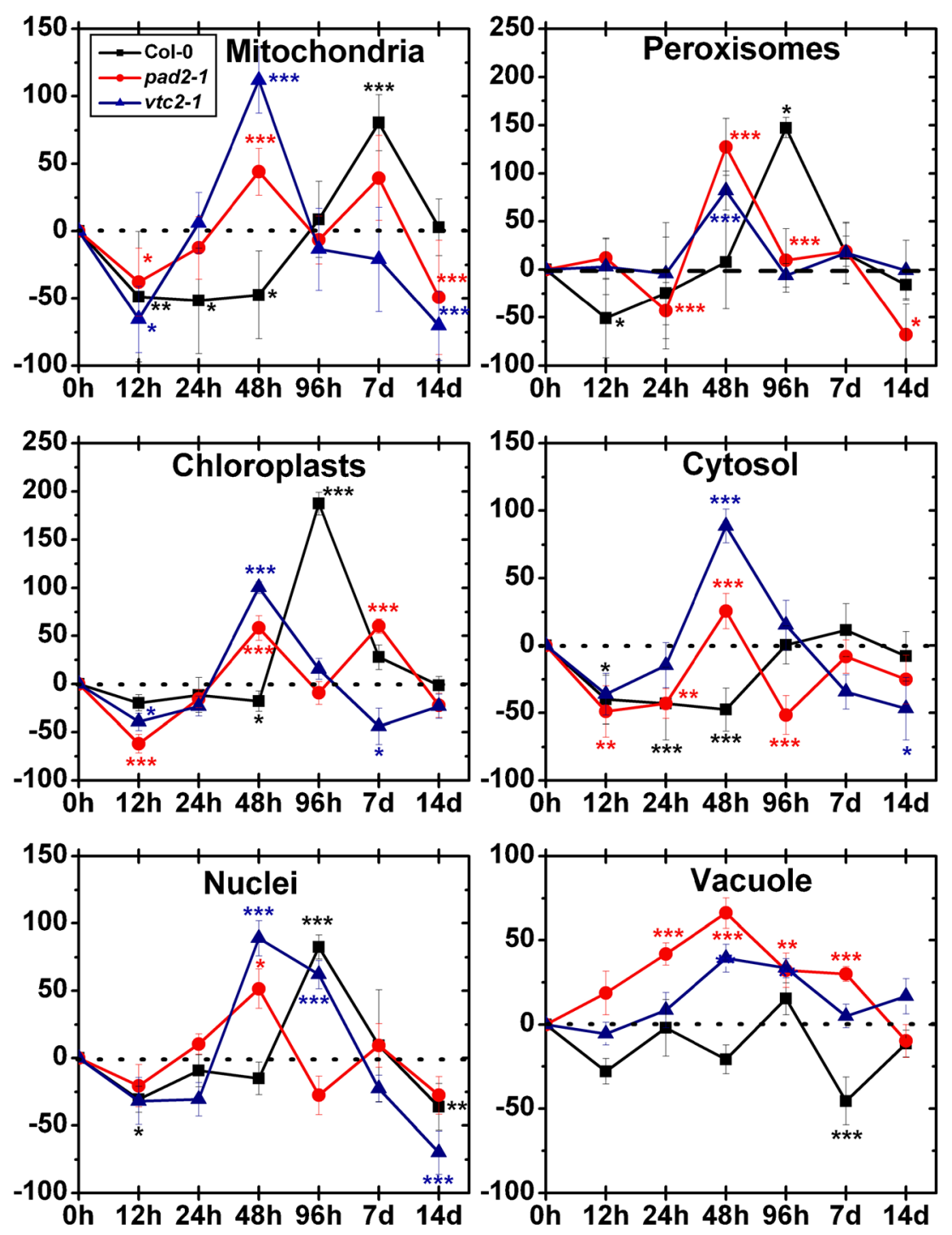

significantly after $12 \mathrm{~h}(-37 \%)$ and $24 \mathrm{~h}(-32 \%)$. Generally, the ascorbate levels in the cytosol where significantly decreased (up to $-43 \%$ ). In peroxisomes, the numbers of gold particles bound to ascorbate increased after $96 \mathrm{~h}(109 \%)$ compared to the control whereas after $12 \mathrm{~h}(-50 \%), 24 \mathrm{~h}(-47 \%)$ and 14 days (-64\%) significant decreased ascorbate levels could be observed. The vacuole showed decreased levels of ascorbate after $12 \mathrm{~h}(-33 \%), 24 \mathrm{~h}(47 \%)$ and 7 days (-36\%) after treatment with $100 \mu \mathrm{M}$ Cd (Fig. 4, Fig. S1).

Mitochondria of pad2-1 mutants showed after $12 \mathrm{~h}(-63 \%)$, $48 \mathrm{~h}(-43 \%), 7$ days ( $-36 \%)$ and 14 days ( $-37 \%)$ significant decreased levels of ascorbate after treatment with $100 \mu \mathrm{M} \mathrm{Cd}$ (Fig. 4). In plastids, the ascorbate levels were generally decreased (between $-13 \%$ and $-66 \%$ ) when compared to the control. In nuclei, significant decreased amounts of gold particles bound to ascorbate could be observed after $48 \mathrm{~h}(-27 \%)$. In the cytosol, the numbers of gold particles where decreased significantly after 12 h, 48 h, 96 h, 7 days and 14 days (between $-36 \%$ and $-65 \%$ ). In peroxisomes, the labeling density of ascorbate showed no significant differences to the control. In the vacuole, significant decreased ascorbate levels could be observed after $12 \mathrm{~h}(-23 \%)$ and 7 days (24\%), whereas after $24 \mathrm{~h}$ the number of gold particles bound to ascorbate increased up to $29 \%$ (Fig. 4, Fig. S2).

After exposure to $100 \mu \mathrm{M} \mathrm{Cd}$, mitochondria of $v t c 2-1$ mutants showed a significant increase of ascorbate levels after $48 \mathrm{~h}(45 \%)$ whereas after 7 days (-51\%) and 14 days $(-54 \%)$ significant decreased levels compared to the control could be observed (Fig. 4). In plastids the amounts of gold particles bound to ascorbate significantly decreased after $12 \mathrm{~h}(-34 \%)$ and $24 \mathrm{~h}(-44 \%)$, whereas after $48 \mathrm{~h}$ increased ascorbate levels compared to the control could be observed (99\%). In nuclei the labeling density of ascorbate was significantly increased after $96 \mathrm{~h}(73 \%)$, whereas decreased levels were found after 14 days $(-56 \%)$. In the cytosol the numbers of gold particles bound to ascorbate significantly increased after $48 \mathrm{~h}(49 \%)$ and $96 \mathrm{~h}(24 \%)$, whereas after 7 days (-46\%) and 14 days $(-37 \%)$ decreased ascorbate levels could be 
Fig. 4 Compartment specific changes in ascorbate labeling density at different time points after the treatment of $100 \mu \mathrm{M} \mathrm{Cd}$. Graphs show the percentage of increase and decrease of gold particles bound to ascorbate per $\mu \mathrm{m}^{2}$ in mesophyll cells of Arabidopsis thaliana Col-0 plants (black squares) and the Arabidopsis mutants pad2-1 (red circles) and vtc2-2 (blue triangles). Differences were calculated by comparing $\mathrm{Cd}$ treated samples with control samples which were treated with nutrient solution without $\mathrm{Cd}$ (values can be found in Table 1). $n>20$ for peroxisomes and vacuoles and $n>60$ for other cell structures. Data are means with standard errors. Significant differences were calculated using the Mann-Whitney $U$-test; *, ** and $* * *$ indicate significance at the $0.05,0.01$ and 0.001 levels of confidence, respectively
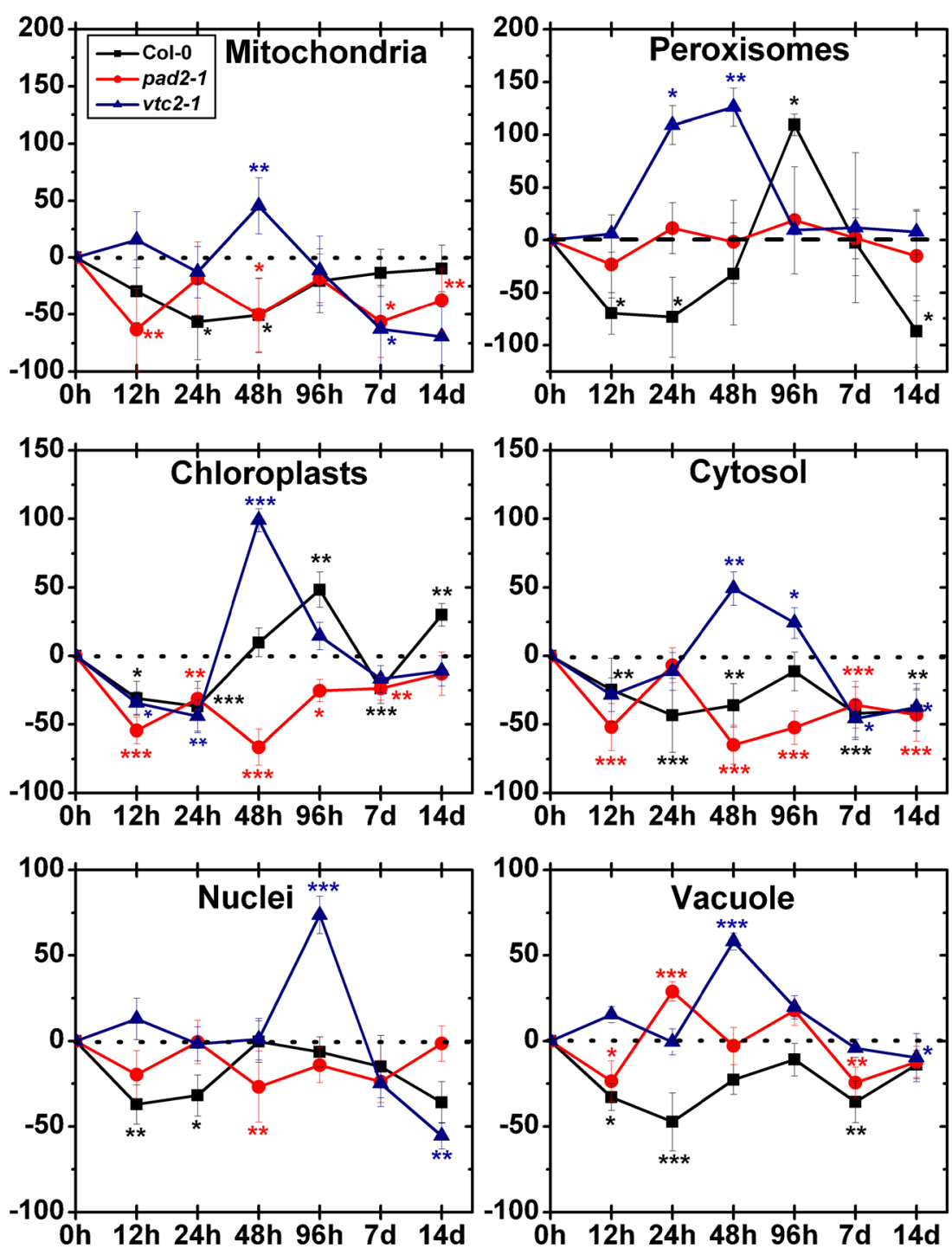

observed. In peroxisomes the labeling density of ascorbate increased significantly after $24 \mathrm{~h}(109 \%)$ and $48 \mathrm{~h}(126 \%)$ compared to the control. In the vacuole a significant higher labeling density of ascorbate could be observed after $48 \mathrm{~h}$ (58\%) compared to the control (Fig. 4, Fig.S3).

Immunogold labeling of glutathione

\section{$50 \mu M C d$}

The subcellular distribution of glutathione in control plants was similar in most cell compartments to what has been reported previously (Zechmann and Müller 2010). Wildtype plants and vtc2-1 mutants contained similar levels of glutathione in all cell compartments whereas the pad2-1 mutant contained between $-87 \%$ and $-71 \%$ less glutathione (nuclei and chloroplasts, respectively) than the wildtype (Table 2). In
Table 2 Values are means with standard errors and document the total amount of gold particles bound to glutathione per $\mu \mathrm{m}^{2}$ in different cell compartments of Arabidopsis thaliana [L.] Heynh. ecotype Columbia (Col-0), pad2-1 and vtc2-1 mutants grown under control conditions

\begin{tabular}{llll}
\hline & Col-0 & pad2-1 & vtc2-1 \\
\hline Mitochondria & $302 \pm 30^{\mathrm{a}}$ & $286 \pm 46^{\mathrm{a}}$ & $240 \pm 15^{\mathrm{ab}}$ \\
Chloroplasts & $35 \pm 5^{\mathrm{f}}$ & $10 \pm 1^{\mathrm{j}}$ & $25 \pm 3^{\mathrm{gi}}$ \\
Nuclei & $209 \pm 34^{\mathrm{bc}}$ & $28 \pm 2^{\mathrm{g}}$ & $160 \pm 13^{\mathrm{cd}}$ \\
Peroxisomes & $109 \pm 12^{\mathrm{e}}$ & $20 \pm 1^{\mathrm{hi}}$ & $82 \pm 10^{\mathrm{e}}$ \\
Cytosol & $130 \pm 17^{\mathrm{de}}$ & $20 \pm 0.8^{\mathrm{g}}$ & $140 \pm 15^{\mathrm{d}}$
\end{tabular}

$n>20$ for peroxisomes and vacuoles and $n>60$ for other cell structures. Different lowercase letters indicate significant differences $(P<0.05)$ analyzed with the Kruskal-Wallis test followed by post-hoc comparison according to Conover 
mitochondria, the pad2-1 mutant contained similar levels of glutathione when compared to the wildtype and the vtc2-1 mutant (Table 2). These results are similar to what has been described in previous studies which revealed that mitochondria of the pad2-1 mutant contained wildtype glutathione levels whereas all other cell compartments contained up to $-90 \%$ less glutathione than the wildtype (Zechmann et al. 2008). Additionally, it has been shown in previous studies that vtc2-1 mutants contain similar glutathione levels when compared to the wildtype (Fernandez-Garcia et al. 2009).

Mitochondria of wildtype plants showed a significant increase of gold particles bound to glutathione after $12 \mathrm{~h}(17 \%), 24 \mathrm{~h}$ (22\%), $48 \mathrm{~h}(69 \%), 7$ days (30 \%) and 14 days (43\%) treatment with $50 \mu \mathrm{M} \mathrm{Cd}$ (Fig. 5). In chloroplasts, elevated glutathione levels between $32 \%$ and $124 \%$ compared to the control could be observed at all time points. In nuclei, increased amounts of gold particles bound to glutathione could be observed after $12 \mathrm{~h}$ (42\%), 24 h (63\%), 48 h (89\%), 96 h (84\%) and 14 days
(90\%) compared to the control. In the cytosol increased glutathione levels were found over the whole experiment (between $45 \%$ and $134 \%$ ) after exposure to $50 \mu \mathrm{M} \mathrm{Cd}$. The amount of gold particles bound to glutathione in peroxisomes significantly increased after exposure to Cd for $12 \mathrm{~h}(104 \%), 24 \mathrm{~h}(53 \%)$, $48 \mathrm{~h}(153 \%)$ and 7 days (23\%; Fig. 5, Fig. S4).

After exposure to $50 \mu \mathrm{M} \mathrm{Cd}$, mitochondria (between $-24 \%$ and $-90 \%$ ), chloroplasts (between $-48 \%$ and $-78 \%$ ) and the cytosol (between $-34 \%$ and $-81 \%$ ) of pad2-1 mutants showed significantly decreased glutathione levels at all time points when compared to the control (Fig. 5). Generally, glutathione labeling in nuclei was significantly decreased (between $-23 \%$ and $-86 \%$ ) until 14 days, where surprisingly a significant increase of $62 \%$ could be observed (Fig. 5, Fig. S5). Peroxisomes showed significantly decreased amounts of gold particles bound to glutathione after $\mathrm{Cd}$ treatment for $12 \mathrm{~h}(-65 \%), 24 \mathrm{~h}(-80 \%), 48 \mathrm{~h}$ $(-81 \%), 7$ days $(-74 \%)$ and 14 days $(-52 \%)$.
Fig. 5 Compartment specific changes in glutathione labeling density at different time points after the treatment of $50 \mu \mathrm{M} \mathrm{Cd}$. Graphs show the percentage of increase and decrease of gold particles bound to glutathione per $\mu \mathrm{m}^{2}$ in mesophyll cells of Arabidopsis thaliana Col-0 plants (black squares) and the Arabidopsis mutants pad2-1 (red circles) and vtc2-2 (blue triangles). Differences were calculated by comparing $\mathrm{Cd}$ treated samples with control samples which were treated with nutrient solution without $\mathrm{Cd}$ (values can be found in Table 2). $n>20$ for peroxisomes and vacuoles and $n>60$ for other cell structures. Data are means with standard errors. Significant differences were calculated using the Mann-Whitney $U$-test; *, ** and $* * *$ indicate significance at the $0.05,0.01$ and 0.001 levels of confidence, respectively
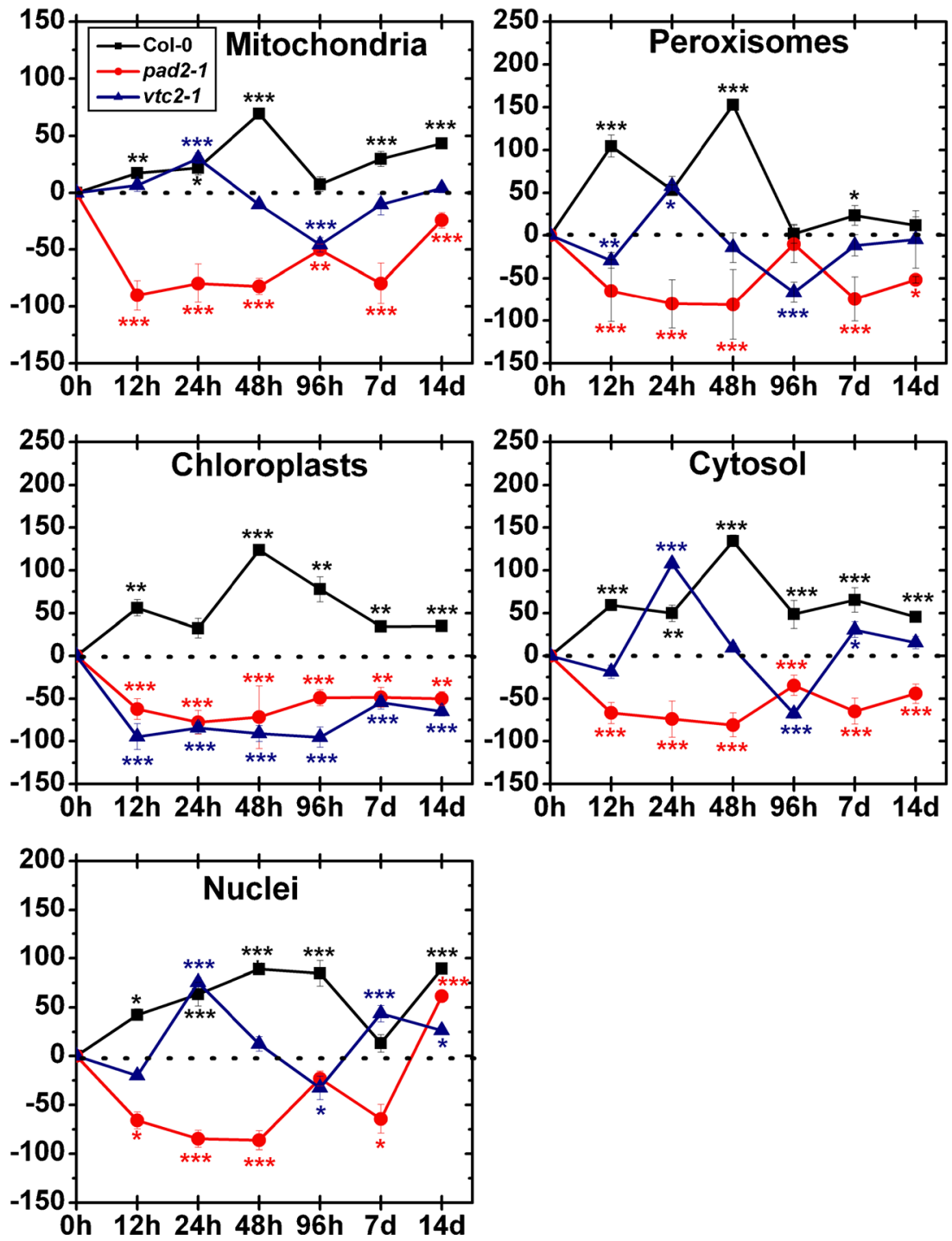
In mitochondria of $v t c 2-1$ mutants the labeling density was significantly increased after $24 \mathrm{~h}(30 \%)$, whereas decreased levels were found after $96 \mathrm{~h}(-46 \%)$ of Cd treatment (Fig. 5). No change was found at the other time points. In chloroplasts the labeling density of glutathione significantly decreased (between $-54 \%$ and $-95 \%$ ) over the whole experiment when compared to the control. Nuclei of vtc2-1 mutants showed significantly higher amounts of gold particles bound to glutathione after $\mathrm{Cd}$ treatment for $24 \mathrm{~h}(75 \%), 7$ days (43\%) and 14 days $(26 \%)$ whereas decreased levels were found after $96 \mathrm{~h}(-33 \%)$. In cytosol, increased amounts of gold particles bound to glutathione could be observed after $24 \mathrm{~h}(107 \%)$ and 7 days $(31 \%)$ compared to the control whereas a significant decrease of $-68 \%$ could be analyzed after $\mathrm{Cd}$ treatment for $96 \mathrm{~h}$. In peroxisomes, the gold particle density decreased $-29 \%$ and $-66 \%$ after $\mathrm{Cd}$ treatment for $12 \mathrm{~h}$ and $96 \mathrm{~h}$ whereas after $24 \mathrm{~h}$ the number of gold particles bound to glutathione increased up to $58 \%$ compared to the control (Fig. 5, Fig. S6).

\section{$100 \mu M C d$}

Mitochondria of wildtype plants showed significantly higher amounts of gold particles bound to glutathione after treatment with $100 \mu \mathrm{M}$ Cd for $48 \mathrm{~h}(54 \%)$ and 7 days (50\%) whereas decreased levels were found after $12 \mathrm{~h}(-83 \%)$ and 14 days ( $-30 \%$, Fig. 6). In chloroplasts, significantly decreased glutathione levels could be observed after $12 \mathrm{~h}(-84 \%)$ and increased levels after $48 \mathrm{~h}$ (68 \%), $96 \mathrm{~h}$ (58 \%), 7 days (137\%) and 14 days (90\%) when compared to the control. After $12 \mathrm{~h}$ the gold particle density in nuclei was significantly decreased $(-69 \%)$ whereas after $48 \mathrm{~h}, 96 \mathrm{~h}$ and 7 days an increase between $62 \%$ and $94 \%$ compared to the control could be observed. The cytosol showed significantly decreased amounts of gold particles bound to glutathione after $\mathrm{Cd}$ treatment for $12 \mathrm{~h}(-73 \%)$ and 14 days $(-25 \%)$ and increased amounts after $48 \mathrm{~h}(70 \%), 96 \mathrm{~h}(78 \%)$ and 7 days (165\%) compared to the control. Twelve hours and 14 days after exposure to $\mathrm{Cd}$, the labeling density in peroxisomes significantly decreased (between $45 \%$ and $68 \%$ ), while after 24 h, $48 \mathrm{~h}$ and 7 days increased amounts of gold particles (between $50 \%$ and $149 \%$ ) could be observed (Fig. 6, Fig. S4).

Significantly decreased glutathione labeling could be observed in mitochondria (between $-25 \%$ and $-90 \%$ ), chloroplasts (between $-59 \%$ and $-83 \%$ ) and cytosol (between $-41 \%$ and $80 \%$ ) of pad2-1 mutants at all time points after exposure to $100 \mu \mathrm{M} \mathrm{Cd}$. In nuclei and peroxisomes, the numbers of gold particles bound to glutathione were generally decreased (between $-31 \%$ and $-85 \%$ in nuclei and between $-63 \%$ and $-88 \%$ in peroxisomes), and no change was found after $96 \mathrm{~h}$ compared to the control (Fig. 6, Fig. S5).

At all time points the exposure to $\mathrm{Cd}$ significantly decreased labeling density in mitochondria (between $-16 \%$ and $-49 \%$ ) and the cytosol (between $-22 \%$ and $-47 \%$ ) in vtc2-1 mutants. Generally, glutathione labeling in chloroplasts was significantly decreased for the first 7 days (between $-39 \%$ and $-69 \%$ ) whereas 14 days after $\mathrm{Cd}$ exposure an increase of $49 \%$ compared to the control could be observed. The amount of gold particles bound to glutathione in nuclei significantly decreased after exposure to $\mathrm{Cd}$ for $48 \mathrm{~h}(-32 \%)$, $96 \mathrm{~h}(-28 \%)$ and 7 days (-40\%). In peroxisomes significantly decreased glutathione levels (between $40 \%$ and $56 \%$ ) were found after the exposure to $\mathrm{Cd}$ for $24 \mathrm{~h}, 96 \mathrm{~h}, 7$ days and 14 days (Fig. 6; Fig. S6).

\section{Discussion}

In general, pad2-1 and vtc2-1 mutants were more sensitive to the exposure to $\mathrm{Cd}$ than wildtype plants. After the exposure to Cd both mutants showed symptoms earlier than the wildtype and developed stronger signs of chlorosis and necrosis which covered larger areas of the leaves. pad2-1 mutants which contain up to $90 \%$ less glutathione than wildtype plants (Parisy et al. 2006; Zechmann et al. 2008) showed even higher sensitivity to $\mathrm{Cd}$ exposure than vtc2-1 mutants as symptoms occurred earlier and stronger than in vtc2-1 mutants. Throughout the experiment, the higher sensitivity of pad2-1 and vtc2-1 mutants could be correlated to much lower glutathione contents when compared to Col-0, which indicates the importance of glutathione for the protection of plants against Cd stress. Similar results as those observed in this study have also been obtained for the glutathione deficient cad2-1 mutant and plants with artificially reduced glutathione contents which also showed higher $\mathrm{Cd}$ sensitivity due to low glutathione contents (Howden et al. 1995; Wójcik and Tukiendorf 2011). It was also shown that increased glutathione contents in the $c d r 3-1 D$ mutants are partially required for enhanced $\mathrm{Cd}$ resistance (Wang et al. 2011). Even though higher Cd sensitivity of ascorbate deficient mutants has not been documented yet in the literature, such effects seem likely as several physiological studies demonstrated a correlation between low tissue concentrations of ascorbate and glutathione and $\mathrm{Cd}$ sensitivity (Wójcik and Tukiendorf 2011). Thus, we can conclude that higher $\mathrm{Cd}$ sensitivity of glutathione and ascorbate deficient mutants are due to lower antioxidative capacity of these plants when compared to wildtype plants.

In this respect, it is interesting that glutathione contents in all cell compartments of wildtype plants followed recently proposed antioxidative stress models (Tausz et al. 2004; Kranner et al. 2010) which correlated well with symptom development on the leaves (Fig. 7). In wildtype plants exposed to $50 \mu \mathrm{M} \mathrm{Cd}$ which showed only minor symptoms 14 days after treatment, glutathione contents increased immediately after $\mathrm{Cd}$ exposure and remained at high levels until the end of the experiment indicating an acclimation effect of these 
Fig. 6 Compartment specific changes in glutathione labeling density at different time points after the treatment of $100 \mu \mathrm{M} \mathrm{Cd}$. Graphs show the percentage of increase and decrease of gold particles bound to glutathione per $\mu \mathrm{m}^{2}$ in mesophyll cells of Arabidopsis thaliana Col-0 Arabidopsis mutants pad2-1 (red circles) and vtc2-2 (blue triangles). Differences were calculated by comparing $\mathrm{Cd}$ treated samples with control samples which were treated with nutrient solution without $\mathrm{Cd}$ (values can be found in Table 2). $n>20$ for peroxisomes and vacuoles and $n>60$ for other cell structures. Data are means with standard errors. Significant differences were calculated using the Mann-Whitney $U$-test; *, ** and $* * *$ indicate significance at the $0.05,0.01$ and 0.001 levels of confidence, respectively plants (black squares) and the
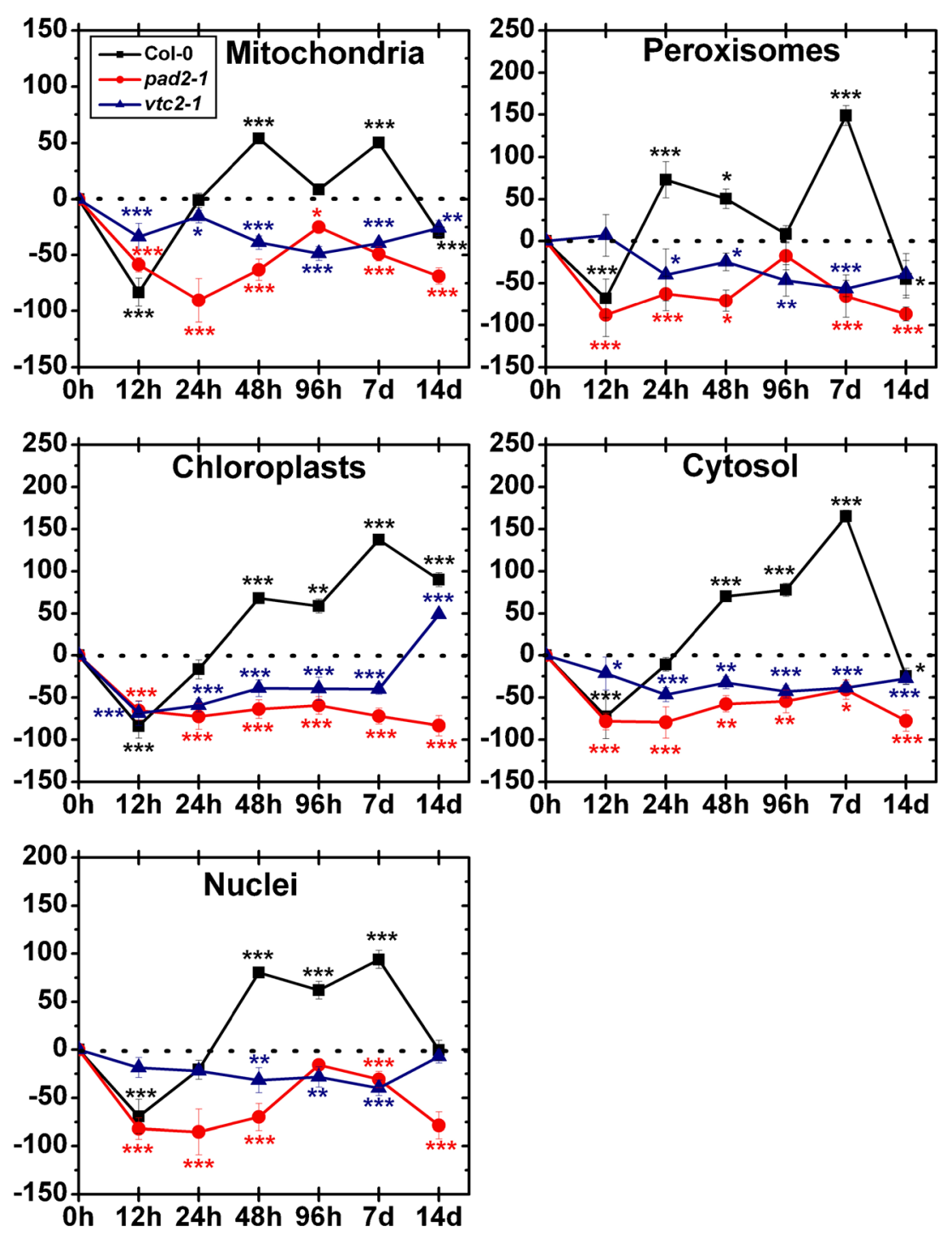

Fig. 7 Line drawing showing a response curve of the overall ascorbate and glutathione labeling of Col-0, pad2-1, and vtc2-1 to treatment with different concentrations of $\mathrm{Cd}$. The relative ascorbate and glutathione content was obtained according to Koffler et al. (2013) using the corresponding labeling density during $\mathrm{Cd}$ treatment and the relative compartment volume from the leaf center, where the sum runs over all compartments. The alarming phase is indicated with the letter "A", the resistance phase is indicated with the letter "R", and the exhaustion phase is indicated with the letter "E". Black line glutathione, grey line ascorbate, asterisk appearance of symptoms

\section{$50 \mu \mathrm{M} \mathrm{Cd}$}

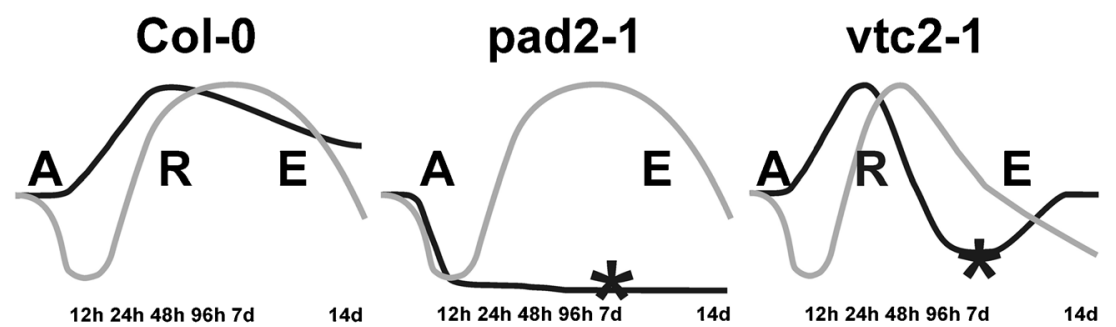

$100 \mu \mathrm{M} \mathrm{Cd}$

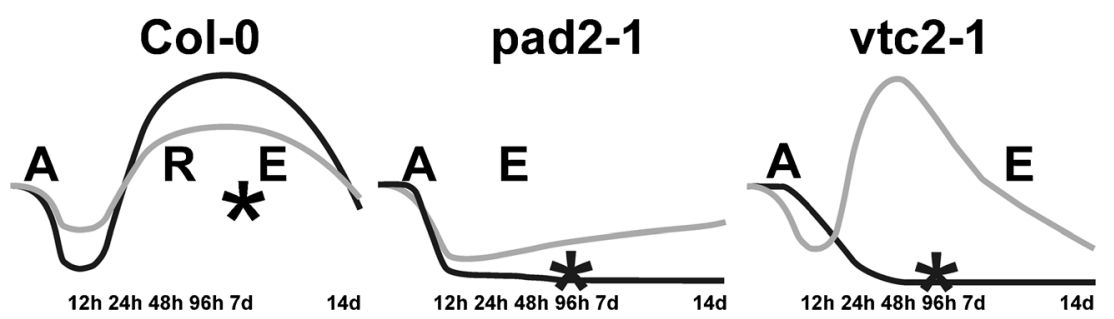


plants to the exposure to $\mathrm{Cd}$ similar to what was described by Tausz et al. (2004). Ascorbate contents reacted in these plants with an initial decrease in ascorbate contents (initial alarming phase), a strong increase in ascorbate contents (resistance phase) and a strong decrease in ascorbate contents (final exhaustion phase; Fig. 7). As strong symptoms remain minor or absent in these plants, these results indicate that high glutathione contents rather than high ascorbate protect plants from $\mathrm{Cd}$ induced symptoms in the long term. Wildtype plants exposed to $100 \mu \mathrm{M}$ showed a typical bell shaped stress response curve (Kranner et al. 2010) with an immediate decrease in glutathione and ascorbate contents which indicates an excessive demand for antioxidants immediately after the exposure to $\mathrm{Cd}$ (Fig. 7). Such a reaction of plants to excess $\mathrm{Cd}$ seems likely as $\mathrm{Cd}$ has a high affinity to thiol groups and would bind to reduced glutathione present in the cytosol after entering the cells (Semane et al. 2007; DalCorso et al. 2008; Jozefczak et al. 2012). Additionally, glutathione is used for the increased production of PCs which are also involved in the detoxification of Cd (DalCorso et al. 2008; Jozefczak et al. 2012). On top both antioxidants play important roles to prevent the accumulation of ROS which is commonly observed during the exposure of plants to heavy metals (Gill and Tuteja 2010; Yadav 2010). Nevertheless, considering that Cd enters the cytosol first and is not relocated into other cell compartments except vacuoles (Van Belleghem et al. 2007) it is interesting that glutathione and ascorbate decreased in all other cell compartments at similar rates. These results are similar to what we have observed for glutathione contents in previous studies (Kolb et al. 2010) and indicates that glutathione and ascorbate are either withdrawn from the other cell compartments to assuage the higher demand of glutathione in the cytosol or that less freshly produced ascorbate and glutathione get transported from the origin of synthesis (e.g., mitochondria for ascorbate [Bartoli et al. 2000; Millar et al. 2003], plastids and cytosol for glutathione [Wachter et al. 2005]) to the other cell compartments as they are used for $\mathrm{Cd}$ and ROS detoxification in the cytosol. This initial phase is then followed by a strong accumulation of glutathione and ascorbate (Fig. 7) which indicates an acclimation or resistance phase where the plant is successfully coping with the environmental stress condition (Tausz et al. 2004; Kranner et al. 2010). Nevertheless, wildtype plants exposed to $100 \mu \mathrm{M} \mathrm{Cd}$ obviously could not withstand Cd stress successfully in the long term as symptoms such as chlorosis and necrotic spots across the leaves could be observed 14 days after $\mathrm{Cd}$ exposure. These symptoms could be correlated with a strong decrease in glutathione contents in most cell compartments at this time point. Additionally, ascorbate contents remained at or below control levels in most cell compartments (Fig. 7) indicating that these plants went through an exhaustion phase which is characterized by failure of protection and repair mechanisms (Kranner et al. 2010) and led to strong symptoms such as the appearance of chlorosis and necrotic spots.

Glutathione contents in pad2-1 mutants which showed highest sensitivity to $\mathrm{Cd}$ were in general decreased in all cell compartments throughout the treatment with 50 and $100 \mu \mathrm{M}$ $\mathrm{Cd}$ (Fig. 7). This strong decrease was correlated with strong symptom development early after Cd treatment (e.g., $96 \mathrm{~h}$ after treatment with $100 \mu \mathrm{M} \mathrm{Cd}$ ) indicating that low glutathione levels in this mutant which contains up to $90 \%$ less glutathione than wildtype plants (Parisy et al. 2006; Zechmann et al. 2008) were unable to protect plants against the toxic effects of Cd (Fig. 7). Similar effects have also been found in plants with artificially decreased glutathione contents and for the glutathione deficient mutant cad2-1 which showed higher $\mathrm{Cd}$ sensitivity correlated with low glutathione contents (Howden et al. 1995; Wójcik and Tukiendorf 2011). Considering that pad2-1 mutants showed the highest sensitivity to $\mathrm{Cd}$, it becomes obvious that the accumulation of ascorbate in pad2-1 mutants treated with $50 \mu \mathrm{M} \mathrm{Cd}$ were not able to compensate low glutathione contents in order to prevent symptom development induced by the accumulation of ROS commonly observed during Cd treatment (Gill and Tuteja 2010; Yadav 2010). On the subcellular level, it is interesting that higher $\mathrm{Cd}$ sensitivity correlated with a strong reduction of glutathione in mitochondria. The pad2-1 mutant is characterized by low glutathione contents in all cell compartments (up to $90 \%$ less than Col-0) and wildtype glutathione levels in mitochondria. Additionally, we have recently demonstrated that high and stable levels of glutathione in mitochondria of the pad2-1 mutants are important for proper plant development (Zechmann and Müller 2010). Thus, the strong decrease of glutathione contents in mitochondria observed in this study of up to $90 \%$ in this mutant could be a key factor for higher $\mathrm{Cd}$ sensitivity.

$v t c 2-1$ mutants reacted to treatment of $50 \mu \mathrm{M} \mathrm{Cd}$ with a bell-shaped stress-response curve (Kranner et al. 2010) in most cell compartments with an initial decrease of glutathione and ascorbate followed by a strong accumulation of both antioxidants and a final drop to or below control values (Fig. 7). vtc2-1 mutants treated with $100 \mu \mathrm{M} \mathrm{Cd}$ showed a strong decrease of glutathione contents similar to the pad2-1 mutants but reacted with a strong increase of ascorbate contents after 48 days. Nevertheless, similar to the pad2-1 mutants, a strong decrease of both antioxidants could be observed in the long term at $100 \mu \mathrm{M} \mathrm{Cd}$ treatment which correlates well with symptom development such as chlorosis and necrosis on the leaves. In this respect it is remarkable that the vtc2-1 mutants which have impaired ascorbate synthesis leading to $60 \%$ less ascorbate in the tissue when compared to Col-0 (Conklin et al. 2000; Zechmann et al. 2011c) reacted with a strong increase in ascorbate contents upon $\mathrm{Cd}$ treatment (observed mainly at 48 and $96 \mathrm{~h}$ after treatment). Similar results have also been observed during exposure to high light where 
$v t c 2-1$ mutants surprisingly reacted with an increase in ascorbate contents despite distorted ascorbate synthesis (MüllerMoulé et al. 2004).

On the subcellular level, it is interesting that gold particles bound to glutathione could not be detected in vacuoles even in Cd-treated samples. It is commonly accepted that glutathione forms complexes with $\mathrm{Cd}$ through the thiol groups which are then sequestered in vacuoles (Rauser 2001; Maksymiec and Krupa 2006; Semane et al. 2007; DalCorso et al. 2008; Jozefczak et al. 2012). Thus, the lack of labeling in vacuoles in Cd-treated samples indicates that the glutathione antibody method used in this study detects free glutathione only. These results are supported by previous labeling experiments which showed the lack of labeling in vacuoles of Arabidopsis leaf disks treated with monochlorobimane which are similar to $\mathrm{Cd}$ bound to the thiol groups of reduced glutathione and then transported into vacuoles (Queval et al. 2011). Long-term exposure to $\mathrm{Cd}$ (14 days) induced the depletion of glutathione and ascorbate contents in all cell compartments except chloroplasts. These results indicate an important role for antioxidants in chloroplasts for the protection of plants against $\mathrm{Cd}$. It is well known that $\mathrm{Cd}$ inhibits photosynthesis as it disturbs the synthesis of chlorophyll and carotenoids, inhibits the enzyme activity of the Calvin cycle and leads to $\mathrm{CO}_{2}$ deficiency due to stomatal closure, which cause the inhibition of the photosynthesis (Ding et al. 2006). As glutathione and ascorbate decreased in all other cell compartments, these results indicate that the plant accumulated antioxidants in chloroplasts at the expense of ascorbate and glutathione of the other cell compartments. This is especially interesting as the cytosol is supposed to be the primary cell compartment for $\mathrm{Cd}$ detoxification as it is not distributed to other cell compartments except vacuoles (Van Belleghem et al. 2007). Thus, the long-term accumulation of ascorbate and glutathione in chloroplasts indicates that the plant redistributes glutathione and ascorbate into chloroplasts during long-term $\mathrm{Cd}$ exposure most probably to detoxify ROS produced during photosynthesis.

\section{Conclusion}

Summing up, we can conclude that ascorbate and glutathione deficient mutants showed higher sensitivity to $\mathrm{Cd}$. Nevertheless, glutathione deficient pad2-1 mutants showed even higher sensitivity to $\mathrm{Cd}$ and reacted to $\mathrm{Cd}$ with a strong decrease in glutathione contents similar to vtc2-1 mutants. As symptom development seemed to be related with low glutathione contents rather than low ascorbate contents (Fig. 7), it seems that low glutathione contents rather than low ascorbate contents are responsible for the high $\mathrm{Cd}$ sensitivity in these plants.
Acknowledgement This work was supported by the Austrian Science Fund (FWF 22988-B16).

Conflict of interest The authors declare that they have no conflict of interest.

Open Access This article is distributed under the terms of the Creative Commons Attribution License which permits any use, distribution, and reproduction in any medium, provided the original author(s) and the source are credited.

\section{References}

Akhter F, McGarvey B, Macfie SM (2012) Reduced translocation of cadmium from roots is associated with increased production of phytochelatins and their precursors. J Plant Physiol 169: 1821-1829

Anjum NA, Umar S, Ahmad A et al (2008) Sulphur protects mustard (Brassica campestris L.) from cadmium toxicity by improving leaf ascorbate and glutathione. Plant Growth Regul 54:271-279

Aravind P, Prasad MNV (2005) Modulation of cadmium-induced oxidative stress in Ceratophyllum demersum by zinc involves ascorbateglutathione cycle and glutathione metabolism. Plant Physio Biochem 43:107-116

Bartoli CG, Pastori GM, Foyer CH (2000) Ascorbate biosynthesis in mitochondria is linked to the electron transport chain between complexes III and IV. Plant Physiol 123:335-343

Baryla A, Carrier P, Franck F et al (2001) Leaf chlorosis in oilseed rape plants (Brassica napus) grown on cadmium-polluted soil: causes and consequences for photosynthesis and growth. Planta 212:696709

Bouzon ZL, Ferreira EC, dos Santos R, Scherner F, Horta PA, Maraschin $M$, Schmidt EC (2012) Influences of cadmium on fine structure and metabolism of Hypnea musciformis (Rhodophyta, Gigartinales) cultivated in vitro. Protoplasma 249:637-650

Van Belleghem F, Cuypers A, Semane B et al (2007) Subcellular localization of cadmium in roots and leaves of Arabidopsis thaliana. New Phytol 173:495-508

Benavides MP, Gallego SM, Tomaro ML (2005) Cadmium toxicity in plants. Braz J Plant Physiol 17:21-34

Cairns NG, Pasternak M, Wachter A et al (2006) Maturation of Arabidopsis seeds is dependent on glutathione biosynthesis within the embryo ${ }^{1[\mathrm{C}]}$. Plant Physiol 141:446-455

Chao Y, Hong C, Chen C, Kao CH (2011) The importance of glutathione in defence against cadmium-induced toxicity of rice seedlings. Crop, Environ Bioinforma 8:217-228

Chen YX, He YF, Luo YM et al (2003) Physiological mechanism of plant roots exposed to cadmium. Chemosphere 50:789-793

Clemens S, Schroeder J, Degenkolb T (2001) Caenorhabdites elegans expresses a functional phytochelatin synthase. Eur J Biochem 268: 3640-3643

Conklin PL, Saracco SA, Norris SR, Last RL (2000) Identification of ascorbic acid-deficient Arabidopsis thaliana mutants. Genetics 154: $847-856$

DalCorso G, Farinati S, Furini A (2010) Regulatory networks of cadmium stress in plants. Plant Signal Behav 5:663-667

DalCorso G, Farinati S, Maistri S, Furini A (2008) How plants cope with cadmium: staking all on metabolism and gene expression. J Integr Plant Biol 50:1268-1280

Ding B, Shi G, Xu Y et al (2006) Physiological responses of Alternanthera philoxeroides (Mart.) Griseb leaves to cadmium stress. Environ Pollut 147:800-803 
Ekmekci Y, Tanyolac D, Ayhan B (2008) Effects of cadmium on antioxidant enzyme and photosynthetic activities in leaves of two maize cultivars. J Plant Physiol 165:600-611

Fernandez-Garcia N, Marti MC, Jimenez A, Sevilla F, Olmos E (2009) Sub-cellular distribution of glutathione in an Arabidopsis mutant (vtc1) deficient in ascorbate. J Plant Physiol 166:2004-2012

Foyer CH, Noctor G (2005) Redox homeostasis and antioxidant signaling: a metabolic interface between stress perception and physiological responses. Plant Cell 17:1866-1875

Foyer CH, Noctor G (2011) Ascorbate and glutathione: the heart of the redox hub. Plant Physiol 155:2-18

Gallego SM, Pena LB, Barcia RA et al (2012) Unravelling cadmium toxicity and tolerance in plants: insight into regulatory mechanisms. Environ Exp Bot 83:33-46

Gill SS, Tuteja N (2010) Reactive oxygen species and antioxidant machinery in abiotic stress tolerance in crop plants. Plant Physiol Biochem 48:909-9030

Gratão PL, Polle A, Lea PJ, Azevedo RA (2005) Review: making the life of heavy metal-stressed plants a little easier. Funct Plant Biol 32: 481-494

Gratão PL, Monteiro CC, Antunes AM et al (2008) Acquired tolerance of tomato (Lycopersicon esculentum cv. Micro-Tom) plants to cadmium-induced stress. Ann Appl Biol 153:321-333

Gratão PL, Monteiro CC, Rossi ML et al (2009) Differential ultrastructural changes in tomato hormonal mutants exposed to cadmium. Environ Exp Bot 67:387-394

Gratão PL, Monteirob CC, Carvalhoa RF et al (2012) Biochemical dissection of diageotropica and Never ripe tomato mutants to Cd-stressful conditions. Plant Physiology and Biochemistry 56:79-96

He J-Y, Ren Y-F, Zhu C et al (2008) Effect of Cd on growth, photosynthetic gas exchange, and chlorophyll fluorescence of wild and $\mathrm{Cd}$ sensitive mutant rice. Photosynthetica 46:466-470

Hegedüs A, Erdei S, Horváth G (2001) Comparative studies of $\mathrm{H}_{2} \mathrm{O}_{2}$ detoxifying enzymes in green and greening barley seedlings under cadmium stress. Plant Sci 160:1085-1093

Howden R, Andersen CR, Coldsbrough B, Cobbett CS (1995) A cadmium-sensitive, glutathione-deficient mutant of Arabidopsis thaliana. Plant Physiol 107:1067-1073

Iannone MF, Rosales EP, Groppa MD, Benavides MP (2010) Reactive oxygen species formation and cell death in catalase-deficient tobacco leaf disks exposed to cadmium. Protoplasma 245:15-27

Jozefczak M, Remans T, Vangronsveld J, Cuypers A (2012) Glutathione is a key player in metal-induced oxidative stress defenses. Int J Mol Sci 13:3145-3175

Keunen E, Remans T, Opdenakker K et al (2013) A mutant of the Arabidopsis thaliana LIPOXYGENASE1 gene shows altered signalling and oxidative stress related responses after cadmium exposure. Plant Physiol Biochem 63:272-280

Koffler BE, Bloem E, Zellnig G, Zechmann B (2013) High resolution imaging of subcellular glutathione concentrations by quantitative immunoelectron microscopy in different leaf areas of Arabidopsis. Micron 45:119-128

Kolb D, Müller M, Zellnig G, Zechmann B (2010) Cadmium induced changes in subcellular glutathione contents within glandular trichomes of Cucurbita pepo L. Protoplasma 243:87-94

Kranner I, Minibayeva FV, Beckett RP, Seal CE (2010) What is stress? Concepts, definitions and applications in seed science. New Phytol 188:655-673

Liu Y, Wang X, Zeng G et al (2007) Cadmium-induced oxidative stress and response of the ascorbate-glutathione cycle in Bechmeria nivea (L.) Gaud. Chemosphere 69:99-107

Maksymiec W, Krupa Z (2006) The effects of short-term exposition to $\mathrm{Cd}$, excess $\mathrm{Cu}$ ions and jasmonate on oxidative stress appearing in Arabidopsis thaliana. Environ Exp Bot 57:187-194

Maughan SC, Pasternak M, Cairns N et al (2010) Plant homologs of the Plasmodium falciparum chloroquine-resistance transporter, PfCRT, are required for glutathione homeostasis and stress responses. PNAS 107:2331-2336

Mendoza-cózatl DG, Butko E, Springer F et al (2008) Identification of high levels of phytochelatins, glutathione and cadmium in the phloem sap of Brassica napus. A role for thiol-peptides in the longdistance transport of cadmium and the effect of cadmium on iron translocation. Plant J 54:249-259

Millar AH, Mittova V, Kiddle G et al (2003) Control of ascorbate aynthesis by respiration and its implications for stress responses. Plant Physiol 133:443-447

Mohamed AA, Castagna A, Ranieri A, Sanità di Toppi L (2012) Cadmium tolerance in Brassica juncea roots and shoots is affected by antioxidant status and phytochelatin biosynthesis. Plant Physiol Biochem 57:15-22

Monteiro CC, Carvalho RF, Gratão PL et al (2011) Biochemical responses of the ethylene-insensitive Never ripe tomato mutant subjected to cadmium and sodium stresses. Environ Exp Bot 71:306-320

Müller-Moulé P, Golan T, Niyogi KK (2004) Ascorbate-deficient mutants of Arabidopsis grow in high light despite chronic photooxidative stress. Plant Physiol 134:1163-1172

Noctor G, Mhamdi A, Chaouch S et al (2012) Glutathione in plants: an integrated overview. Plant Cell Environ 35:454-484

Noriega G, Caggiano E, Lecube ML et al (2012) The role of salicylic acid in the prevention of oxidative stress elicited by cadmium in soybean plants. Biometals 25:1155-1165

Paradiso A, Berardino R, De Pinto MC et al (2008) Increase in ascorbateglutathione metabolism as local and precocious systemic responses induced by cadmium in durum wheat plants. Plant Cell Physiol 49: 362-374

Parisy V, Poinssot B, Owsianowski L et al (2006) Identification of PAD2 as a $\gamma$-glutamylcysteine synthetase highlights the importance of glutathione in disease resistance of Arabidopsis. Plant J 49:159-172

Queval G, Jaillard D, Zechmann B, Noctor G (2011) Increased intracellular $\mathrm{H} 2 \mathrm{O} 2$ availability preferentially drives glutathione accumulation in vacuoles and chloroplasts. Plant Cell Environ 34:21-32

Rauser WE (2001) The role of glutathione in plant reaction and adaptation to excess metals. In: Grill D, Tausz M, Cok LJ (eds) Significance of glutathione to plant adaptation to the environment. Kluwer, Dordrecht, pp 123-154

Sanità di Toppi L, Gabbrielli R (1999) Response to cadmium in higher plants. Environ Exp Bot 41:105-130

Sanità di Toppi L, Pawlik-Skowrońska B, Vurro E et al (2008) First and second line mechanisms of cadmium detoxification in the lichen photobiont Trebouxia impressa (Chlorophyta). Environ Pollut 151: 280-286

Schützendübel A, Polle A (2002) Plant responses to abiotic stresses: heavy metal-induced oxidative stress and protection by mycorrhization. J Exp Bot 53:1351-1365

Semane B, Cuypers A, Smeets K et al (2007) Cadmium responses in Arabidopsis thaliana: glutathione metabolism and antioxidative defence system. Physiol Plantarum 129:519-528

Shan S, Liu F, Chunjuan Li C, Wan S (2012) Effects of cadmium on growth, oxidative stress and antioxidant enzyme activities in peanut (Arachis hypogaea L.) seedlings. J Agricult Sci 4:142-151

Smeets K, Opdenakker K, Remans T et al (2009) Oxidative stress-related responses at transcriptional and enzymatic levels after exposure to $\mathrm{Cd}$ or $\mathrm{Cu}$ in a multipollution context. J Plant Physiol 166:1982-1992

Smiri M, Chaoui A, Rouhier N et al (2011) Cadmium affects the glutathione/glutaredoxin system in germinating pea seeds. Biol Trace Elem Res 142:93-105

Tausz M, Sircelj H, Grill D (2004) The glutathione system as a stress marker in plant ecophysiology: is a stress-response concept valid? J Exp Bot 55:1955-1962

Vernoux T, Wilson RC, Ka S et al (2000) The ROOT MERISTEMLESS1/CADMIUM SENSITIVE2 gene defines a glutathione-dependent pathway involved in initiation and 
maintenance of cell division during postembryonic root development. Plant Cell 12:97-110

Wachter A, Wolf S, Steininger $\mathrm{H}$ et al (2005) Differential targeting of GSH1 and GSH2 is achieved by multiple transcription initiation: implications for the compartmentation of glutathione biosynthesis in the Brassicaceae. Plant J 41:15-30

Wang Y, Zong K, Jiang L et al (2011) Characterization of an Arabidopsis cadmium-resistant mutant cdr3-1D reveals a link between heavy metal resistance as well as seed development and flowering. Planta 233:697-706

Wójcik M, Tukiendorf A (2011) Glutathione in adaptation of Arabidopsis thaliana to cadmium stress. Biol Plantarum 55:125-132

Xu P, Zou J, Meng Q et al (2008) Effects of Cd(2+) on seedling growth of garlic (Allium sativum L.) and selected physiological and biochemical characters. Bioresource Technol 99:6372-6378

Yadav SK (2010) Heavy metals toxicity in plants: an overview on the role of glutathione and phytochelatins in heavy metal stress tolerance of plants. S Afr J Bot 76:167-179

Zechmann B, Koffler BE, Russell SD (2011a) Glutathione synthesis is essential for pollen germination in vitro. BMC 11:54
Zechmann B, Liou L-C, Koffler BE et al (2011b) Subcellular distribution of glutathione and its dynamic changes under oxidative stress in the yeast Saccharomyces cerevisiae. FEMS 11:631-42

Zechmann B, Stumpe M, Mauch F (2011c) Immunocytochemical determination of the subcellular distribution of ascorbate in plants. Planta 233:1-12

Zechmann B, Mauch F, Sticher L, Müller M (2008) Subcellular immunocytochemical analysis detects the highest concentrations of glutathione in mitochondria and not in plastids. J Exp Bot 59:40174027

Zechmann B, Müller M (2010) Subcellular compartmentation of glutathione in dicotyledonous plants. Protoplasma 246:15-24

Zechmann B, Müller M (2008) Effects of zucchini yellow mosaic virus infection on the subcellular distribution of glutathione and its precursors in a highly tolerant Cucurbita pepo cultivar. Botany 86:1092-1100

Zelinova V, Mistrik I, Pavlovkin J, Tamas L (2013) Glutathione peroxidase expression and activity in barley root tip after short-term treatment with cadmium, hydrogen peroxide and $t$-butyl hydroperoxide. Protoplasma. doi:10.1007/s00709-013-0481-3 